スボーツ造手の身体適性に関する研究（第5 報)

Side steps test の妥当性，信頼度の模討

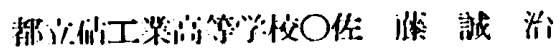

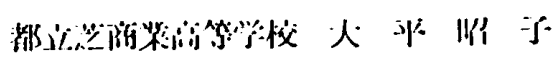

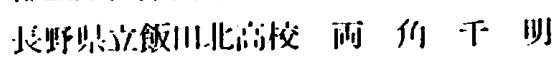

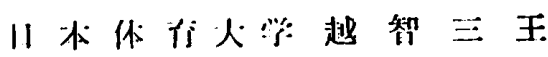

\section{(I) 研究の目的}

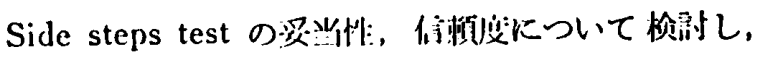

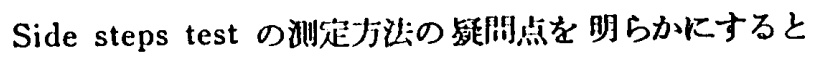

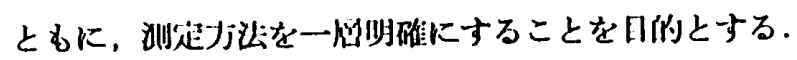

(II) 研究の方法

(1) 测䔎行砳:

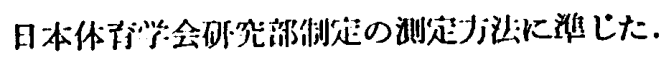

(2) 测定队得

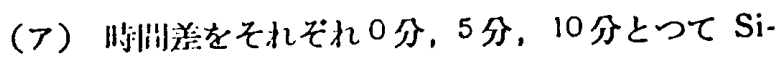
de steps test を5回尤施した。

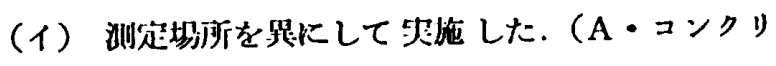
一ト，B・休㐨蛜フロフー，C・グラゥンド，D・アス フフルト,以下 A，B，C，Dとする.)

(3) 测定们月月日及び被臨洪

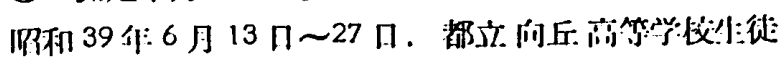

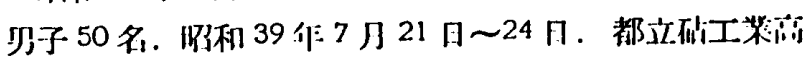

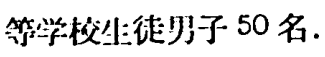

\section{〔III〕赫果及び考案}

\section{A) 㭙润差0分の场合}

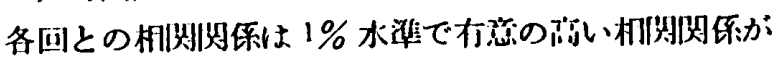
みられた.

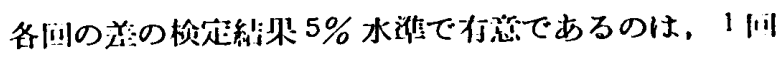

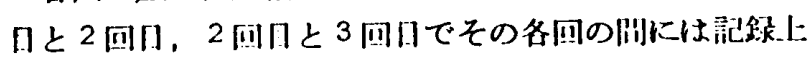

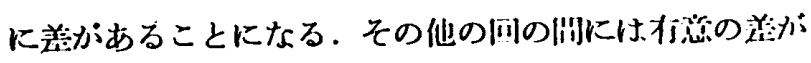
なく捂銀はに希がないことになる。

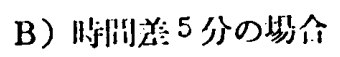

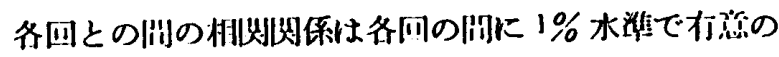

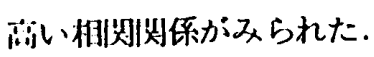

名回の差の梌定和罙 $1 \%$ 水染で有息であるのは，1回

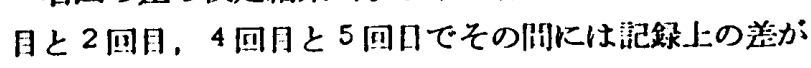
あることになる。

C）综洲差 10 分の埸合

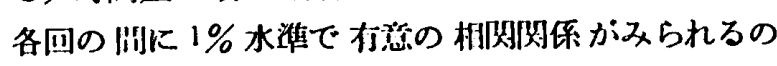
は，1国日と 2 囵日，4国回と5[回田で，3回日と 4 回

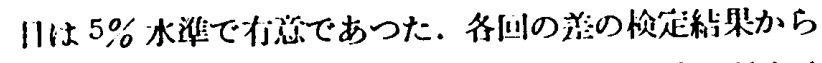

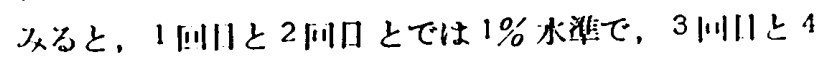

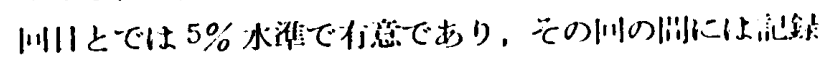
」に渭がめることになる。

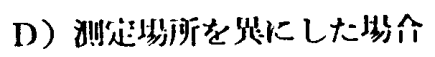

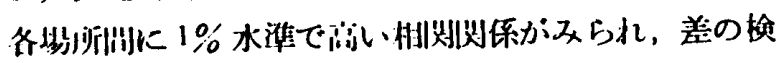
定維染，A，B，C の間には存意でなく差はみとめられ

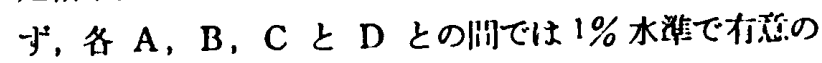
朔がみめられた。

\section{[IV] 结的}

(1) 狩間美と回数については，それぞれ

贴闰普0分の场合は3回日

狩间美5 分の场合は 2 回日

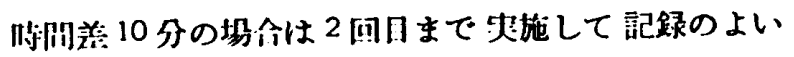
方をとる。いずれにしても1回の大施では信頼度が低く なることになる。

(2) 测定勚坼につ・ては

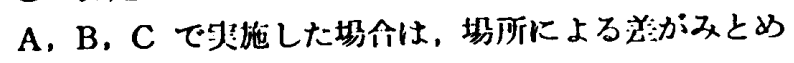
られない。しかし，多くの测定场所によつては孱所によ る於が仙るむのと考えられる。

Side steps test の测定の场介，测定场形によつて剈

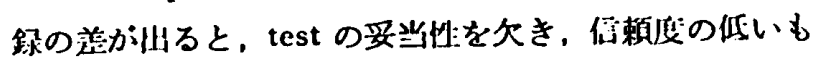
のになる.

以上のことから， Side steps test の测定场的につい

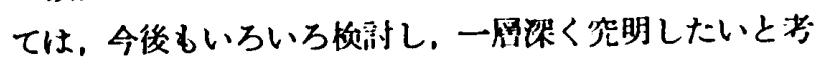
シる。

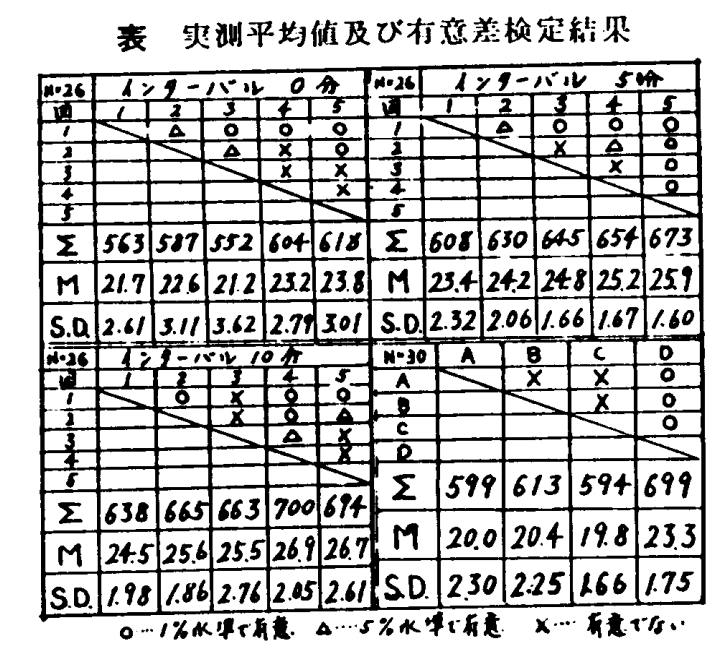

